\title{
Implementasi Pembelajaran Individual Head Number Berbasis Google Meet dan Classroom pada materi Trigonometri
}

\author{
Fanny Ahmad Fauzi ${ }^{1^{*}}$, Puji Lestari ${ }^{2}$ \\ ${ }^{1}$ Magister Pendidikan Matematika, Universitas Siliwangi, Tasikmalaya, Indonesia; \\ fnnahmad@gmail.com \\ ${ }^{1}$ Magister Pendidikan Matematika, Universitas Siliwangi, Tasikmalaya, Indonesia; \\ pujilestari@unsil.ac.id
}

\begin{abstract}
Abstrak. Di era pandemic saat ini, pembelajaran dilakukan secara daring untuk mencegah penyebaran covid-19. Oleh karena itu pendidik dituntut untuk lebih kreatif dan inovatif sehingga tujuan pembelajaran dapat tercapai. Salah satu alternatif pembelajaran daring yang dapat dilakukan adalah Individual Head Number (INH) berbasis Google Meet dan Classroom yang merupakan hasil modifikasi dari model pembelajaran Number Head Together (NHT). Penelitian ini bertujuan untuk mendeskripsikan hasil implementasi Individual Head Number Berbasis Google Meet dan Classroom dalam pembelajaran matematika serta respon siswa terhadap penggunaan Individual Head Number Berbasis Google Meet dan Classroom. Penelitian ini merupakan penelitian studi kasus dengan sampel 12 siswa pada salah satu SMAN di Kabupaten Majalengka. Berdasarkan hasil uji coba terbatas, diperoleh kesimpulan sebagian besar peserta didik senang dengan proses belajar mengajar Individual Head Number berbasis Google Meet dan Classroom dengan 66,7\% senang dan 33,3\% merasa cukup senang. Hasil evaluasi secara umum Individual Head Number berbasis Google Meet dan Classroom dalam pembelajaran matematika materi aturan sinus dan cosinus dengan 53,3\% peserta didik memberikan tanggapan efektif dan 46,7\% memberikan cukup efektif, oleh karena itu disimpulkan bahwa pembelajaran menggunakan metode Individual Head Number berbasis Google Meet dan Classroom efektif digunakan sebagai salah satu alternatif model pembelajaran daring.

Kata Kunci: Pembelajaran daring, Google Classroom, Google Meet, Individual Head Number
\end{abstract}

Abstract. In the current pandemic era, learning is being carried out online to prevent
the spread of covid-19. Therefore, educators are required to be more creative and
innovative so that learning objectives can be achieved. One alternative online
learning that can be done by Individual Head Numbers (INH) based on Google Meet
and Classroom which is a modified result of the Number Head Together (NHT)
learning model. This study aims to describe the results of the implementation of
Google Meet and Classroom-based Individual Head Numbers in mathematics
learning. as well as student responses to the use of Google Meet and Classroom Based
Individual Head Numbers. This research is a qualitative descriptive study with a 
sample of 13 students of State Senior High School (SMA) in Majalengka Regency. Based on the results of limited trials, it is concluded that most of them are happy with the teaching and learning process with Google Meet and Classroom based Individual Head Numbers with $66.7 \%$ happy and $33.3 \%$ feeling quite happy. Then the results of the general evaluation of Google Meet and Classroom-based Individual Head Numbers in mathematics learning material sine and cosine rules with $53.3 \%$ giving effective responses and $46.7 \%$ giving quite effective, therefore the authors conclude that learning uses the Individual Head Number method. based on Google Meet and Classroom, it is effectively used as an alternative online learning model.

Keywords: Online Learning, Google Classroom, Google Meet, Individual Head Number

\section{Pendahuluan}

Berdasarkan Keputusan Bersama Kementerian Pendidikan dan Kebudayaan, Kementerian Agama, Kementerian Kesehatan dan Kementerian Dalam Negeri bahwa satuan pendidikan dapat melaksanakan pembelajaran tatap muka jika berada di zona hijau (Aminah, 2020) Artinya satuan pendidikan yang berada di zona kuning, orange dan merah tetap melaksanakan pembelajaran secara daring. Dalam situasi seperti ini, guru dituntut untuk lebih kreatif dan mampu memanfaatkan teknologi yang ada sehingga pembelajaran daring tidak hanya sekedar memberikan rangkuman materi dan tugas melalui media sosial. Penggunaan media pembelajaran yang memanfaatkan TIK dapat menjadikan pembelajaran matematika lebih mudah dan menarik (Widjayanti et al., 2018).

Terdapat beberapa media pembelajaran yang dapat digunakan untuk pembelajaran daring di era pandemi saat ini, diantaranya adalah virtual class dan video conference (selanjutnya disebut vicon). Virtual Class adalah sebuah konsep pembelajaran yang terdiri dari satu kelompok/kelas yang secara bersamaan peserta tersebut berpartisipasi dalam pembelajaran jarak jauh dari lokasi tempat mereka berada yang terhubung dengan platform yang sama (Raes et al., 2020). Pembelajaran daring dilakukan dengan bantuan smartphone yang terkoneksi dengan internet yang merupakan media dalam mobile learning. Mobile learning merupakan salah satu pemanfaatan teknologi informasi dan komunikasi untuk media pembelajaran yang bersifat interaktif dalam proses pembelajaran, sehingga proses belajar siswa dapat menarik dan tidak terbatas oleh ruang dan waktu (Siti Suprihatiningsih et al., 2020). Beberapa virtual class yang dapat digunakan dalam pembelajaran jarak jauh adalah Edmodo, Edpuzle, Google Classroom, Schoology, namun ada juga sekolah yang mengembangkan Learning Management System (LMS) sendiri.

Copyright (C) 2020

Buana Matematika :

Jurnal Ilmiah Matematika dan Pendidikan Matematika 
Selain virtual classroom, pembelajaran daring dapat dilakukan dengan menggunakan aplikasi video conference seperti Google Meet, Zoom, Webex dan lain sebagainya. Aplikasi tersebut dapat digunakan di smartphone yang dimiliki oleh mayoritas peserta didik sebagai salah satu pendukung pembelajaran daring.

Fakta di lapangan partisipasi peserta didik dalam pembelajaran daring masih kurang maksimal, berdasarkan laporan KBM salah satu SMA di kabupaten Majalengka pada tanggal 16 November 2020 yang mengikuti pembelajaran daring matematika wajib di kelas XI Mipa 5 hanya 60\%. Selain itu, berdasarkan hasil penelitian (Tauhid et al., 2020) dengan kesimpulan Pembelajaran dinilai efektif pada sebelum pandemic sebesar $58,8 \%$ menurun pada saat pandemin sebesar $41,2 \%$.

Oleh karena itu, inovasi-inovasi dari guru penting dilakukan agar pembelajaran daring menjadi lebih menarik, efektif layaknya pembelajaran tatap muka. Seperti yang penelitian (Nurhayati \& Lestari, 2020) yang berjudul Pembelajaran Berbasis Whatsapp dan Flash Game Player, namun ada kekurangannya yaitu dalam pembuatan media pembelajaran berbasis macromedia flash dibutuhkan waktu yang lumayan lama karena perlu memahami bahasa pemprogramannya terlebih dahulu. Akibat keterbatasan guru dalam pengusaan teknologi dan keterbatasan waktu untuk mempelajarinya, sehingga guru hanya memanfaatkan teknologi seadaanya seperti Whatsapp dan Instagram, padahal guru dapat berinovasi sehingga tujuan pembelajaran dapat tercapai dengan baik. Salah satu inovasi yang dapat dijadikan alternatif pada pembelajaran daring di era pandemik saat ini adalah pembelajaran Individual Number Head berbasis google meet dan google classroom.

Google meet adalah adalah salah satu aplikasi atau software vicon yang dikembangkan oleh Google yang dapat dimanfaatkan untuk proses pembelajaran secara daring. Keunggulan Google Meet menurut (Idcloudhost, 2020) adalah.

a. Membantu para pekerja dan karyawan untuk tetap melakukan rapat dimana saja mereka berada dengan menggunakan video call.

b. Interface atau antarmuka yang unik dan fungsional dengan ukuran ringan serta cepat, mengedepankan pengelolaan yang efisien, mudah guna (user friendly) yang dapat diikuti semua pesertanya.

c. Pengguna dapat mengundang peserta rapat dan berbagi fitur.

Copyright (C) 2020

Buana Matematika :

Jurnal Ilmiah Matematika dan Pendidikan Matematika 
Google Classroom merupakan sebuah aplikasi yang memungkinkan terciptanya ruang kelas di dunia maya. Selain itu, google classroom bisa menjadi sarana distribusi tugas, submit tugas bahkan menilai tugas-tugas yang dikumpulkan (Nirfayanti \& Nurbaeti, 2019). Aplikasi ini membantu guru dan peserta didik dalam proses belajar mengajar secara daring di era pandemi seperti saat ini, sehingga pembelajaran akan lebih terstuktur dengan beberapa fitur yang ada pada Google Classroom. Melalui fasilitas yang disediakan oleh sistem tersebut, pembelajar dapat brlangsung kapan dan dimana saja tanpa terbatas oleh jarak, ruang dan waktu (Hikmatiar et al., 2020).

Google classroom sesungguhnya dirancang untuk mempermudah interaksi guru dan peserta didik dalam dunia maya (Nirfayanti \& Nurbaeti, 2019). Aplikasi ini memberikan kesempatan kepada para guru untuk mengeksplorasi gagasan keilmuan yang dimilikinya kepada peserta didik. Guru memliki keleluasaan waktu untuk membagikan kajian keilmuan dan memberikan tugas mandiri kepada peserta didik selain itu, guru juga dapat membuka ruang diskusi bagi para peserta didik secara online. Namun demikian, terdapat syarat mutlak dalam mengaplikasikan google classroom yaitu membutuhkan akses internet yang mumpuni.

Model Pembelajaran Individual Head Number ( selanjutkan disebut INH) adalah suatu model pembelajaran yang dimodifikasi dari model Numbered Head Together (selanjutnya disebut NHT). Model pembelajaran NHT merupakan bagian dari model pembelajaran kooperatif yang identik dengan kerja kelompok (Wijayati et al., 2011). Model Pembelajaran INH dengan NHT adalah pendekatan pembelajarannya, INH menggunakan pendekatan non koperatif, pembelajaran NHT menggunakan pendekatan koperatif. Model pembelajaran NHT menekankan siswa untuk saling bekerja sama dalam kelompok sehingga masing-masing anggota kelompok paham dengan hasil kerja kelompoknya dan bertanggung jawab terhadap hasil kerja tersebut, sehingga dengan sendirinya siswa merasa dirinya harus terlibat aktif dalam proses pembelajaran. Model pembelajaran INH menekankan siswa untuk bekerja secara mandiri dan bertanggungjawab terhadap hasil kerja tersebut, sehingga diharapkan setiap individu dapat terlibat aktif dalam proses pembelajaran.

Berdasarkan uraian diatas individual head number berbasis google meet dan classroom diharapkan menjadi sebuah inovasi pembelajaran yang dapat menarik minat peserta didik, terlebih dimasa pembelajaran jarak jauh ini. Dengan demikian tujuan penelitian ini adalah mendeskripsikan hasil Copyright (C) 2020

\section{Buana Matematika :}

Jurnal Ilmiah Matematika dan Pendidikan Matematika 
implementasi diatas individual head number berbasis google meet dan classroom dalam pembelajaran matematika, serta mendeskripsikan respon siswa terhadap pembelajaran tersebut.

\section{Metode}

Metode penelitian yang digunakan dalam penelitian ini adalah studi kasus. Studi kasus adalah studi tentang kekhususan dan kompleksitas suatu kasus tunggal dan berusaha untuk mengerti kasus tersebut dalam konteks, situasi, dan waktu tertentu (Raco, 2020). Studi kasus termasuk dalam penelitian analisis deskriptif, yaitu penelitian yang dilakukan terfokus pada suatu kasus tertentu untuk diamati dan dianalisis secara umum sampai tuntas. Kasus yang dimaksud bisa berupa tunggal atau jamak, misalnya berupa individu atau kelompok. Pada penelitian ini, subjek yang diteliti sebanyak 12 orang peserta didik SMAN di Kabupaten Majalengka. Pemilihan subjek dalam penelitian ini dilakukan secara purposive sampling dengan pertimbangan memiliki perangkat pendukung seperti gadget, memiliki kuota internet, mampu menggunakan aplikasi google meet dan classroom setelah diberikan pengarahan dan memiliki komunikasi yang baik. Langkah-langkah pembelajaran Individual Head Number Berbasis Google Meet dan Classroom yaitu Guru menyampaikan materi pembelajaran atau permasalahan kepada siswa, Guru memberikan kuis secara individual kepada siswa, Guru mengajukan permasalahan untuk dipecahkan secara individu, Guru mengecek pemahaman siswa dengan menyebut salah satu nomor secara random, Diulang kembali langkah 3 dan 4, Guru memberikan penegasan pada akhir pembelajaran, Guru memfasilitasi siswa dalam membuat rangkuman dan mengarahkan, Guru memberikan tes/kuis kepada siswa secara individual, dan Guru memberi reward pada individu. Teknik pengumpulan data dalam penelitian ini berupa pemberian soal tes materi trigonometri yang telah divalidasi sebelumnya secara isi dan muka, dan angket untuk mengukur respon siswa mengenai pembelajarn yang diberikan. Angket yang digunakan adalah skala respon peserta didik dengan bentuk rating scale dengan 5 alternatif jawaban. Pengisian angket dilakukan secara online melalui google form. Teknik analisis data dalam penelitian ini adalah deskripsi hasil tes materi trigonometri dan angket respon peserta didik.

\section{Hasil dan Pembahasan}

Sebelum melaksanakan pembelajaran daring, dibentuk dahulu kelas virtual di Google Classroom dan memberikan pemahaman mengenai classroom dan google meet kepada peserta didik. Pembelajaran terdiri dari dua pertemuan, Copyright (c) 2020

\section{Buana Matematika :}

Jurnal Ilmiah Matematika dan Pendidikan Matematika 
pertemuan pertama dilaksanakan melalui classroom dan pertemuan kedua dilaksanakan melalui google meet.

Peserta didik diinstruksikan untuk bergabung ke kelas yang telah dibuat dengan menggunakan kode kelas yang telah diberikan.

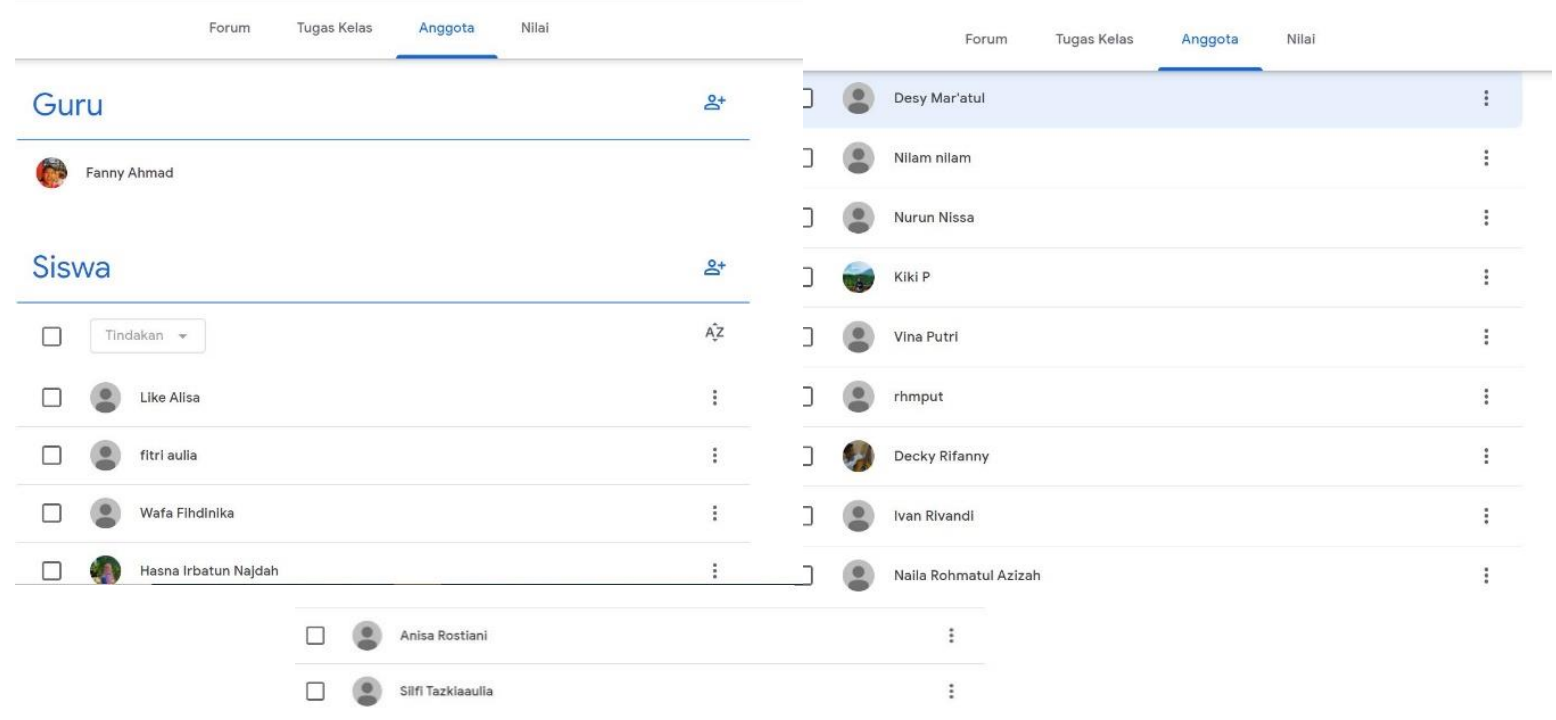

Gambar 1. Peserta Didik yang Sudah Join Classroom

Pada pertemuan pertama, peserta didik diinstruksikan untuk membuka video yang telah di kirim ke kelas, dan memahami materi yang ditelah disajikan.

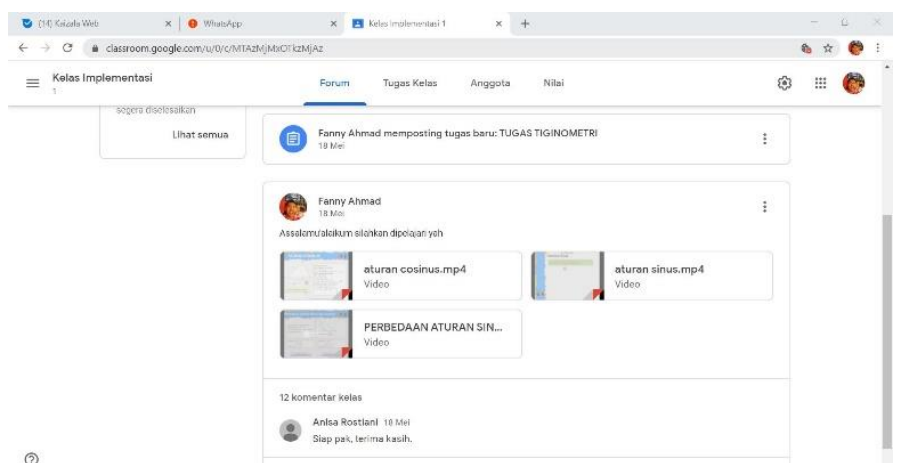

Gambar 2. Pemberian Materi

Copyright $(02020$

Buana Matematika :

Jurnal Ilmiah Matematika dan Pendidikan Matematika 
Peserta didik diberikan latihan soal untuk dikerjakan secara mandiri agar peserta didik lebih paham mengenai materi yang sedang dibahas. Pada tahap ini, peserta didik mengerjakan soal dengan mandiri, setelah ia memahami materi yang diberikan guru.

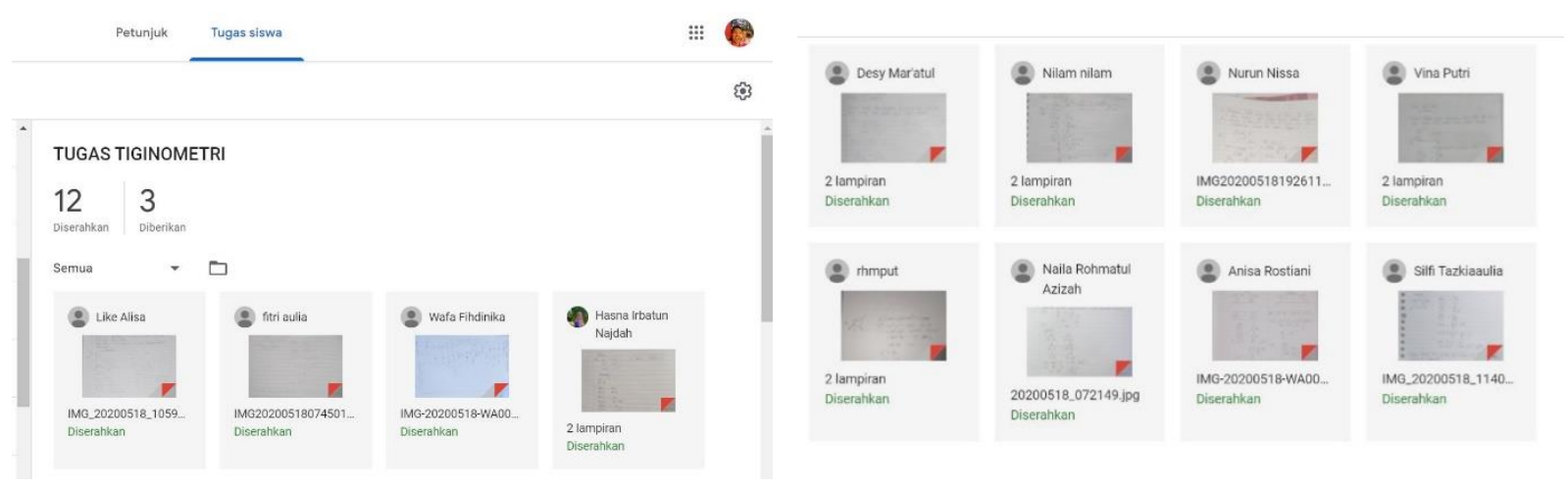

Gambar 3. Peserta didik mengirim tugas

Pada pertemuan kedua, peserta didik diarahkan untuk bergabung di google meet dengan menggunakan link yang telah diberikan. Pada pertemuan kedua ini ada beberapa kendala seperti sinyal, dan peserta didik tidak mempersiapkan nomor kepala, sehingga nomor kepala diganti dengan nomor absen.

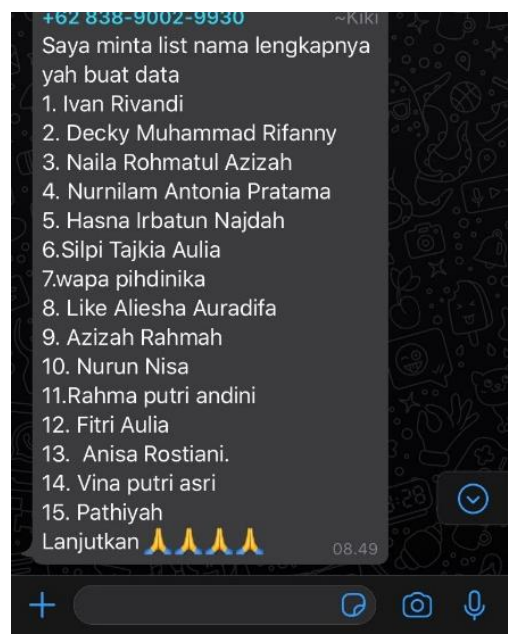

Gambar 4. Nomor Absen 
Untuk melihat pemahaman peserta didik, peserta didik menjelaskan jawaban dari soal yang telah diberikan pada pertemuan sebelumnya, pemilihan peserta didik dengan cara diundi dengan bantuan Microsoft excel.

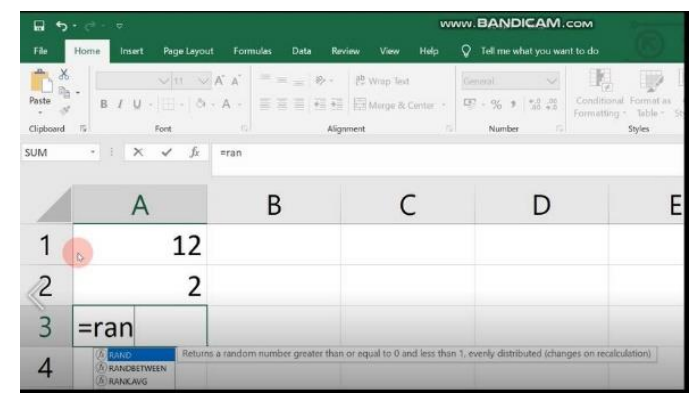

Gambar 5. Pengundian Nomor Absen

Nomor absen yang keluar dari hasil undian tersebut harus menjelaskan jawaban yang sudah ia kerjakan dan siswa yang lain memperhatikannya. Diakhir pembelajaran Guru memberikan penegasan mengenai jawaban yang telah dijelaskan peserta didik.

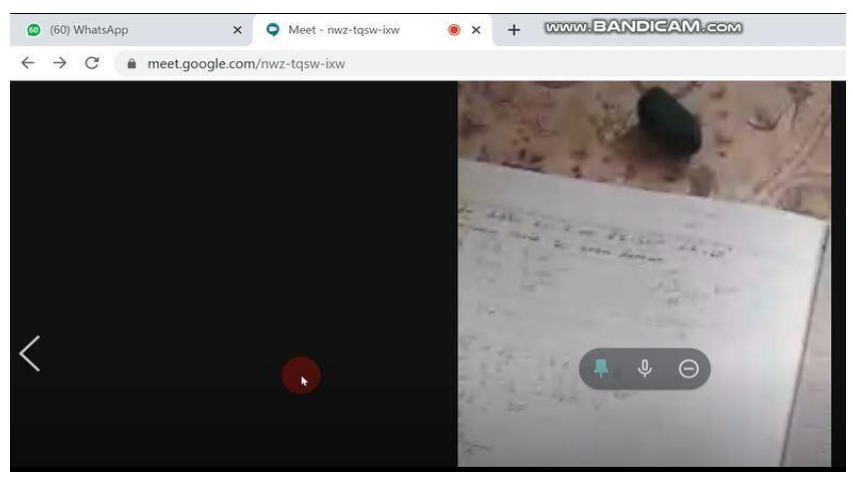

Gambar 6(a).

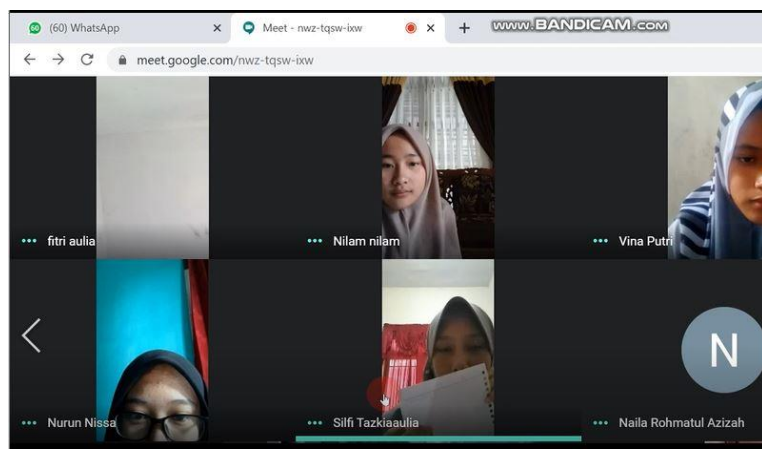

Gambar 6 (b).

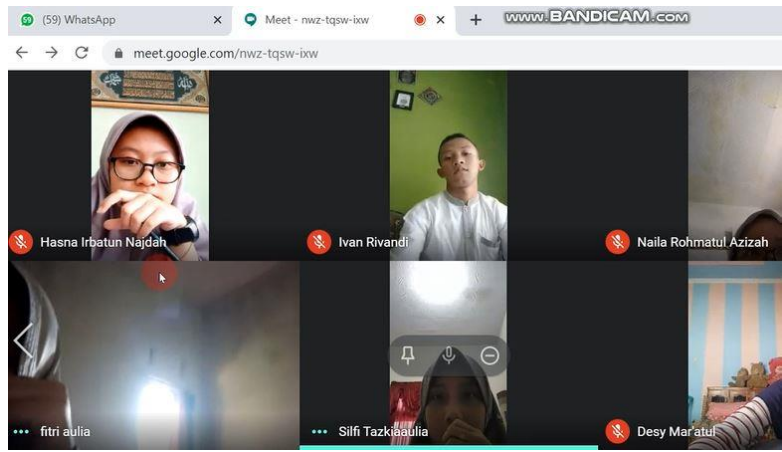

Gambar 6 (c).

Gambar 6(a), (b). Peserta didik sedang menjelaskan jawaban, (c). peserta didik yang lain sedang memperhatikan

Copyright (C) 2020

Buana Matematika :

Jurnal Ilmiah Matematika dan Pendidikan Matematika 
Pada tahap ini ada beberapa kendala diantaranya adalah video yang di share peserta didik buram, hal ini disebabkan oleh kualitas camera handphone peserta didik selain itu sinyal yang kurang stabil menyebabkan kualitas video yang diterima menjadi buram. Namun, untuk mengantisipasi informasi tidak diterima oleh peserta didik lain, solusinya adalah dengan mengirim hasil jawaban masing-masing peserta didik ke grup whatsapp yang telah dibuat, sehingga jawaban masing-masing peserta didik dapat dilihat oleh temantemannya.

Tahap selanjutnya adalah kuis dengan menggunakan google form. Berikut adalah nilai kuis materi trigonometri.

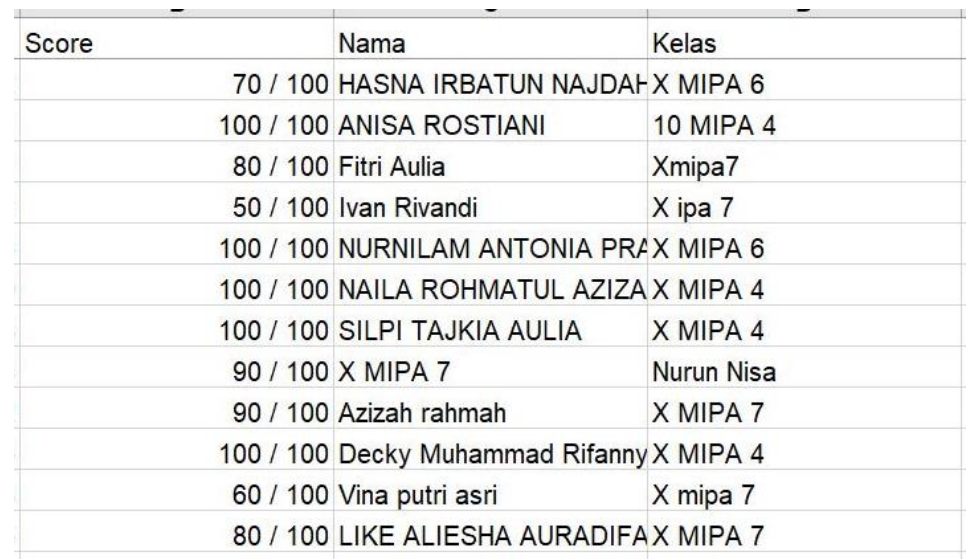

Gambar 7. Nilai Kuis Peserta Didik

Dari hasil kuis diatas, dari 12 orang yang mengikuti pembelajaran hanya 3 orang atau 25\% yang mendapatkan nilai di bawah KKM dan $75 \%$ mendapatkan nilai di atas KKM, bahkan ada 5 orang atau 41,67\% mendapatkan nilai 100 .

Selanjutnya Guru memberikan reward berupa pulsa kepada peserta didik yang paling besar nilainya, dikarenakan banyak yang nilainya 100, maka penulis memberikan reward kepada yang nilainya paling besar dan paling cepat menjawabnya. 

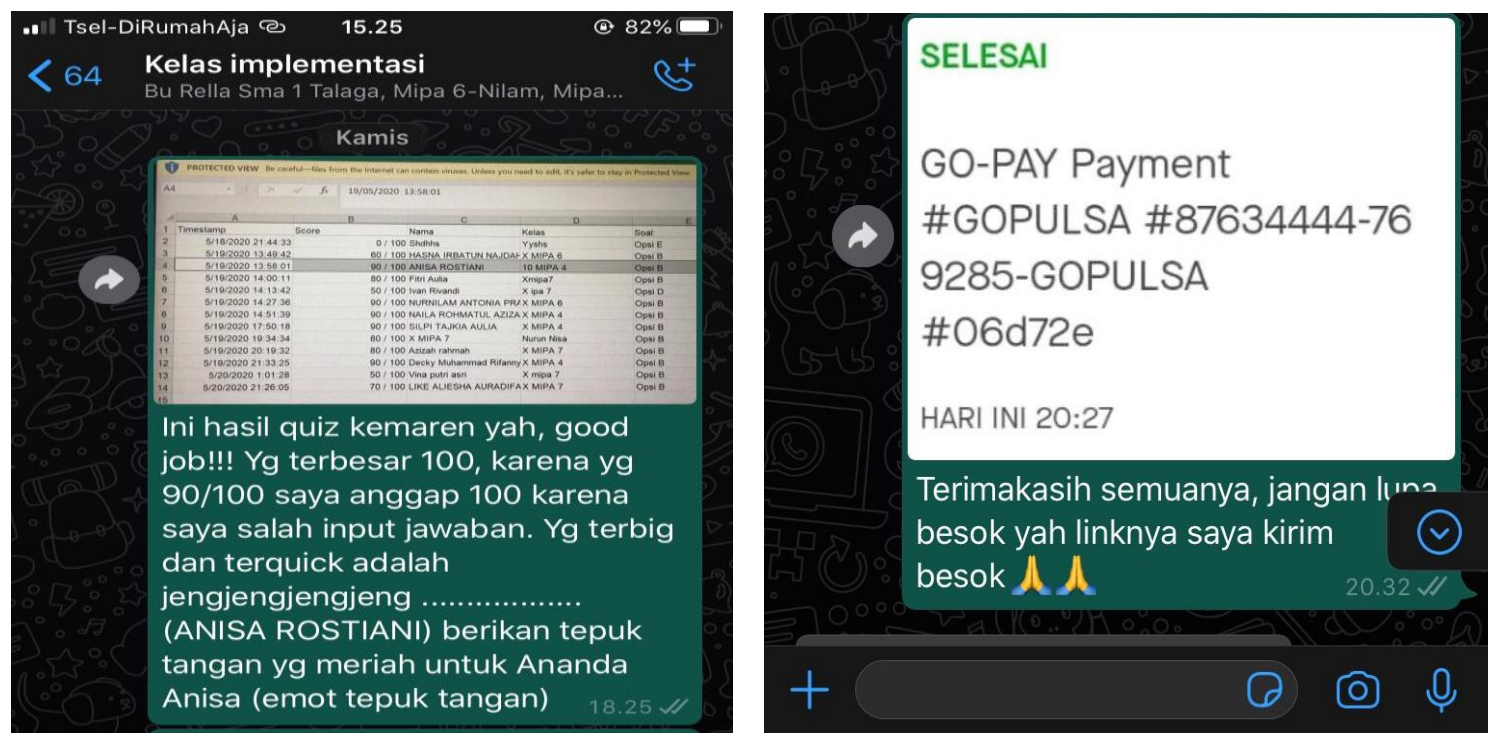

Gambar 8. Pemberian Reward

Sebagai bahan evaluasi, penulis menyebarkan angket kepada peserta didik. Angket tersebut disusun dengan beberapa pertanyaan dan menggunakan rating scale. Tanggapan angket respon peserta didik ditampilkan sebagai berikut.

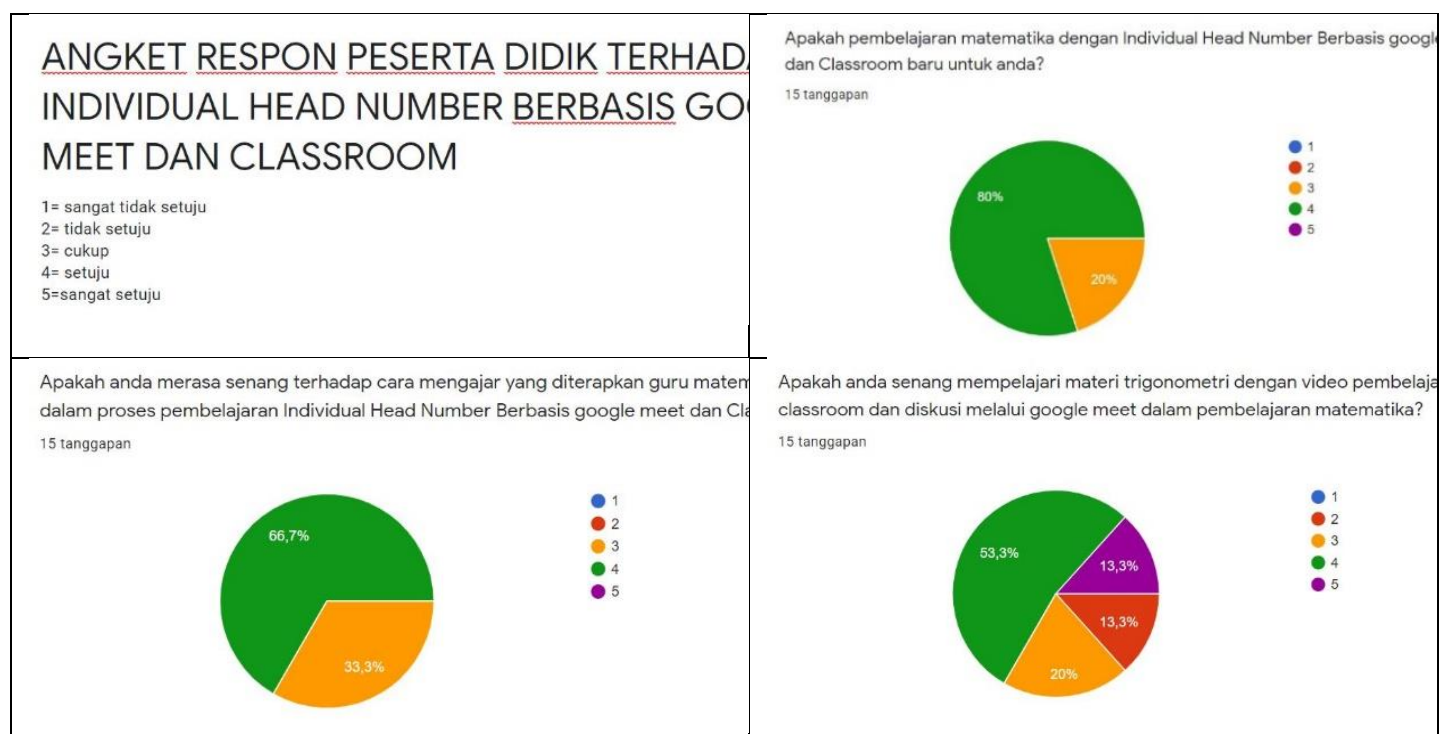

Copyright (C) 2020

\section{Buana Matematika :}

Jurnal Ilmiah Matematika dan Pendidikan Matematika 


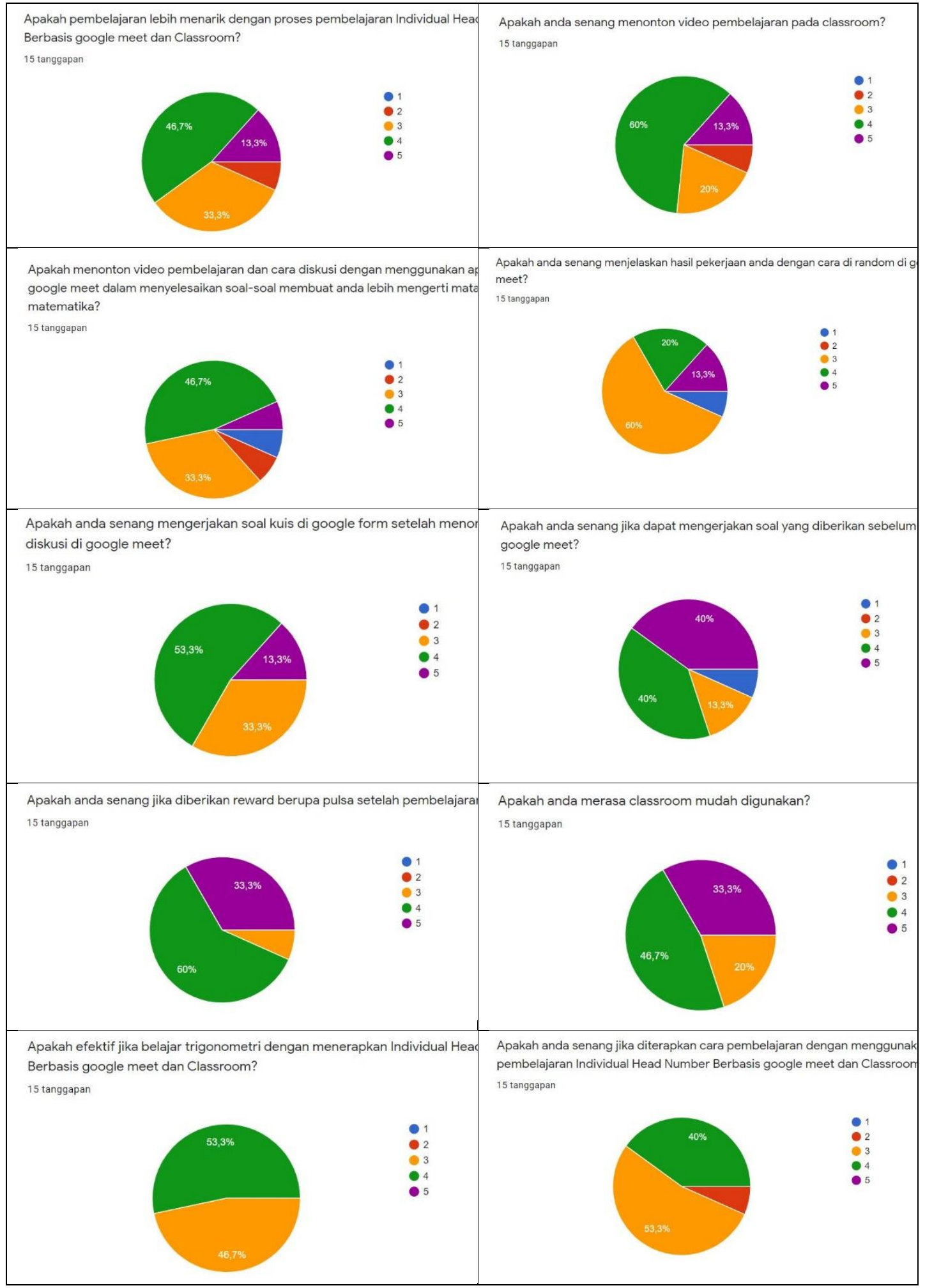

Copyright (c) 2020

Buana Matematika :

Jurnal Ilmiah Matematika dan Pendidikan Matematika 


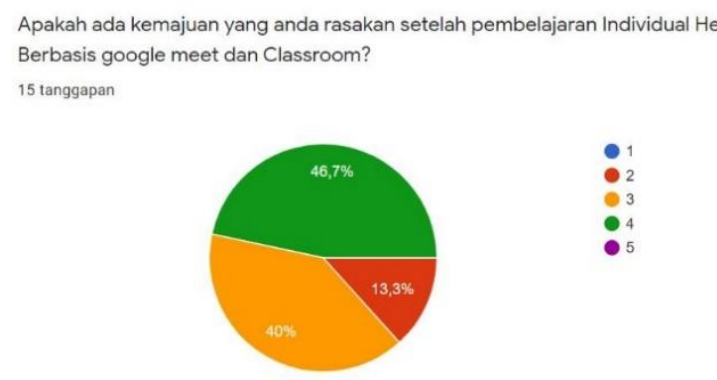

Gambar 9. Tampilan Tanggapan Respon

Dari hasil pengerjaan angket tersebut, hasilnya cukup mengejutkan dan bervariasi. Pembelajaran matematika dengan model individual head number berbasis google meet dan classroom adalah hal yang baru bagi subjek penelitian, mereka senang mempelajari materi trigonometri menggunakan model pembelajaran tersebut. Hanya saja beberapa subjek penelitian kurang menyukai menonton video dan berdiskusi melalui google meet,karena sudah terbiasa belajar tatap muka dan dibimbing langsung. Berdasarkan pengisian angket, Sebagian subjek penelitian setuju jika pembelajaran selanjutnya menggunakan model individual head number berbasis google meet dan classroom, dan Sebagian kecil subjek yang tidak ingin menggunakan model pembelajaran ini. Hal ini disebabkan karena subjek penelitian sudah mulai bosan dengan pembelajaran daring dan menginginkan pembalajran tatap muka. Kemudian 46,7\% subjek penelitian merasakan adanya kemajuan setelah pembelajaran dengan model individual head number berbasis google meet dan classroom, hal ini terbukti dengan hasil pengerjaan tes yang memuaskan. Hasil evaluasi secara umum model individual head number berbasis google meet dalam pembelajaran daring matematika dengan materi trigonometri peserta didik cenderung memberikan tanggapan efektif karena jika peserta didik memiliki kuota internet dan jaringan internet yang stabil.

\section{Simpulan}

Dari hasil pengisian angket, hasilnya sangat bervariatif karena banyak hal yang mempengaruhi peserta didik dalam proses belajar mengajar. Sebagian besar senang dengan proses belajar mengajar dengan Individual Head Number berbasis Google Meet dan Classroom dengan 66,7\% senang dan 33,3\% merasa cukup senang. Kemudian hasil evaluasi secara umum Individual Head Number berbasis Google Meet dan Classroom dalam pembelajaran matematika materi aturan sinus dan cosinus dengan 53,3\% memberikan tanggapan efektif dan $46,7 \%$ memberikan cukup efektif, oleh karena itu penulis dapat menyimpulkan bahwa Individual Head Number berbasis Google Meet dan

Copyright (C) 2020

\section{Buana Matematika :}

Jurnal Ilmiah Matematika dan Pendidikan Matematika 
Classroom efektif digunakan sebagai salah satu alternatif model pembelajaran secara daring.

\section{Ucapan Terima Kasih}

Terimakasih kepada peserta didik yang telah bersedia mengikuti pembelajaran daring, guru matematika SMAN 1 Talaga, Kepala Sekolah SMAN 1 Talaga Kabupaten Majalengka.

\section{Daftar Pustaka}

Aminah, A., N. (2020). (, June). Selain di Zona Hijau, Sekolah Dilarang Tatap Muka. https://republika.co.id/berita/qc29wu384/mendikbud-selain-dizona-hijau-sekolah-dilarang-tatap-muka

Hikmatiar, H., Sulisworo, D., \& Wahyuni, M. E. (2020). Pemanfaatan Learning Manegement System Berbasis Google Classroom Dalam Pembelajaran. Jurnal Pendidikan Fisika, 8(1), 78-86. https://doi.org/10.26618/jpf.v8i1.3019

Idcloudhost. (n.d.). Mengenal Google Meet: Fitur, Keunggulan, dan Cara Menggunakannya. Idcloudhost. https://idcloudhost.com/mengenal-googlemeet-fitur-keunggulan-dan-cara-menggunakannya/

Nirfayanti, N., \& Nurbaeti, N. (2019). Pengaruh Media Pembelajaran Google Classroom Dalam Pembelajaran Analisis Real Terhadap Motivasi Belajar Mahasiswa. Proximal, 2(1), 50-59. https:/ejournal.my.id/proximal/article/view/211

Nurhayati, I., \& Lestari, P. (2020). Pembelajaran Berbasis Whatsapp Dan Flash Game. Maju, 7(2), 28-43.

Raco, J. (n.d.). Metode Penelitian Kualitatif. Grasindo.

Raes, A., Vanneste, P., Pieters, M., Windey, I., Van Den Noortgate, W., \& Depaepe, F. (2020). Learning and instruction in the hybrid virtual classroom: An investigation of students' engagement and the effect of quizzes. Computers and Education, 143(August 2019), 103682. https://doi.org/10.1016/j.compedu.2019.103682

Siti Suprihatiningsih, Nugroho Arif Sudibyo, \& Triana Harmini. (2020). Eksperimentasi Mobile Learning Pada Mata Kuliah Kalkulus Integral Ditinjau Dari Kemampuan Bekerjasama. Buana Matematika: Jurnal Ilmiah Matematika Dan Pendidikan Matematika, 10(1), 17-30.

Copyright (C) 2020

Buana Matematika :

Jurnal Ilmiah Matematika dan Pendidikan Matematika 
https://doi.org/10.36456/buanamatematika.v10i1.2488

Tauhid, S. M., Foldra, F., Jayawinangun, R., \& Pakuan, U. (2020). Trend Kajian Pembelajaran Daring: Suatu Telaah Pustaka. Jurnal Penelitian Sosial Ilmu Komunikasi, 4(September), 157-164.

Widjayanti, W. R., Masfingatin, T., \& Setyansah, R. K. (2018). Media Pembelajaran Interaktif Berbasis Animasi Pada Materi Statistika Untuk Siswa Kelas 7 Smp. Jurnal Pendidikan Matematika, 13(1), 101-112. https://doi.org/10.22342/jpm.13.1.6294.101-112

Wijayati, N., Kusumawatia, I., \& Titik Kushandayani. (2011). Penggunaan Model Pembelajaran Numbered Heads Together Untuk Meningkatkan Hasil Belajar Kimia. Jurnal Inovasi Pendidikan Kimia, 2(2), 281-286.

\section{Riwayat Hidup Penulis}

\section{Fanny Ahmad Fauzi}

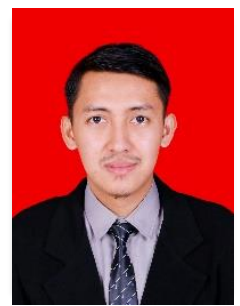

Lahir di Majalengka, 18 September 1996. Staf pengajar di SMA Negeri 1 Talaga. Studi S1 Pendidikan Matematika Universitas Siliwangi, Tasikmalaya, lulus tahun 2019; Publikasi terbaik yang pernah dilakukan adalah pemateri Webinar dan Workshop Pascasarjana Pendidikan Matematika Universitas Siliwangi tahun 2020.

\section{Puji Lestari}

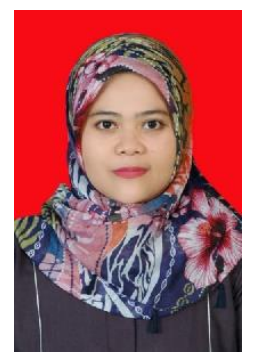

Lahir di Bandung, 8 Januari 1984. Saat ini merupakan dosen di Magister Pendidikan Matematika Universitas Siliwangi, Tasikmalaya. Topik penelitian yang paling diminati adalah pendidikan matematika dan aplikasi teknologi dalam pembelajaran matematika. Saat ini, penulis sedang menempuh studi lanjut jenjang S3 Pendidikan Matematika di Universitas Pendidikan Indonesia. 